\title{
ANALYSIS OF FACTORS INFLUENCING FEMALE INFERTILITY
}

\author{
Ika Indarwati'1), Uki Retno Budi Hastuti²), Yulia Lanti Retno Dewi3) \\ 1)Masters Program in Public Heath, Sebelas Maret University \\ 2)Department of Obstetrics and Gynecology, Dr. Moewardi Hospital, \\ Surakarta \\ 3)Department of Nutrition, Faculty of Medicine, Sebelas Maret University
}

\begin{abstract}
Background: Female infertility is one of important public health problems worldwide. According to the World Health Organization, the incidence of infertile cases is increasing each year. Likewise, according to the Central Bureau of Statistics, infertile incidence in Indonesia has been increasing. Dr. Moewardi Hospital Surakarta is one of the hospitals in Central Java Province with increasing number of infertile patients visits. This study aimed to analyze risk factors influencing female infertility.

Subjects and Method: This was an analytic observational study with case control design. The study was conducted at Sekar Clinic Dr. Moewardi Hospital, Surakarta from February to March, 2017. A sample of 105 fertile women, consisting of 35 infertile women and 70 fertile women, were selected for this study. The dependent variable was infertility. The independent variables were age, maternal employment status, level of stress, body mass index, abnormal reproductive organ. The data were collected by medical record and questionnaires. The data were analyzed by logistic regression.

Results: Female infertility was affected by aged $\geq 35$ years old $(\mathrm{OR}=4.45$; $95 \% \mathrm{CI}=1.27$ to $15.54 ; \mathrm{p}=0.019)$, career women $(\mathrm{OR}=3.91 ; 95 \% \mathrm{CI}=1.14$ to 13.38; $\mathrm{p}=0.043)$, high level of stress $(\mathrm{OR}=3.89 ; 95 \% \mathrm{CI}=1.04$ to $14.46 ; \mathrm{p}=$ 0.046), body mass index $(\mathrm{OR}=4.37 ; 95 \% \mathrm{CI}=1.03$ to $18.61 ; \mathrm{p}<0.001)$, abnormal reproductive organ $(\mathrm{OR}=11.67 ; 95 \% \mathrm{CI}=2.80$ to $48.54 ; \mathrm{p}=0.030)$.

Conclusion: female infertility is affected by aged $\geq 35$ years old, carrer women, high level of stress, body mass index, and abnormal reproductive organ.
\end{abstract}

Keywords: female infertility, age, level of stress, employment status, body mass index

Correspondence: Ika Indarwati. Masters Program in Public Health, Sebelas Maret University, Jl. Ir. Sutami 36 A, Surakarta 57126, Central Java, Indonesia. Email: ikaindarwaty@gmail.com. Mobile: +6285736222215. 